\title{
CONTRIBUTION OF OZONE, pH AND TEMPERATURE IN THE INACTIVATION OF A FOODBORNE PATHOGEN Listeria monocytogenes- A STUDY USING RESPONSE SURFACE METHODOLOGY
}

\author{
${ }^{1}$ Anbazhagi Muthukumar, ${ }^{*}$ 2Muthukumar Muthuchamy \\ ${ }^{*}$ Environmental Engineering and Technology Laboratory, Department of Environmental Sciences, \\ Bharathiar University, Coimbatore, Tamilnadu, India \\ DST Young Scientist Fellow/Principal Investigator,DRDO-BU Center for Life Sciences, \\ Bharathiar University Campus, Coimbatore, Tamilnadu, India \\ Email:sanbazhagi@gmail.com
}

\begin{abstract}
Listeria monocytogenes is a Gram positive ubiquitous psychrotrophic bacterium responsible for foodborne infections worldwide. $L$. monocytogenes is capable of growing at refrigeration temperatures in high salt and acid foods. In this study a response surface methodology was used to determine the effects and interactions of $\mathrm{pH}\left(4\right.$ to 10), temperature $\left(4^{\circ} \mathrm{C}\right.$ to $\left.40{ }^{\circ} \mathrm{C}\right)$ and ozonation time (5 seconds to 60 seconds) on the inactivation of $L$. monocytogenes strains ATCC 19115. The models were validated on Phosphate buffered saline inoculated with $L$. monocytogenes $\left(10^{8} \mathrm{CFU} / \mathrm{mL}\right)$ using a batch reactor. According to the study, the optimum $\mathrm{pH}$ and the temperature for the total inactivation of $L$. monocytogenes falls in the range of $4.5-7.5$ and $4^{\circ} \mathrm{C}-15^{\circ} \mathrm{C}$ respectively. Analysis of Variance showed that the coefficient determination value $\left(R^{2}\right)$ of $L$. monocytogenes inactivation was 0.9429. The study concluded that a 7 log reduction of $L$. monocytogenes can be successfully achieved by ozone exposure between 33 seconds and 49 seconds.
\end{abstract}

Keywords: Listeria monocytogenes; Inactivation; Temperature; Response surface methodology; Time; Ozone.

\section{INTRODUCTION}

Food-borne illnesses are rampant among the human population. Globally, the developed countries are searching for efficient and safe protocols for providing food safety. The best way to reduce incidence of foodborne diseases is to secure safe food supply. Although Hazard Analysis Critical Control Point (HACCP) system has been implemented in many food processing establishments, most outbreaks of food-borne illnesses still occur in the food service sectors including institutions, fast food restaurants, and food stores, where food products had undergone various treatments and considered as safe [1]. This situation indicates that hazards might still exist in the food supply systems. Human listeriosis is predominantly a food-borne disease caused by $L$. monocytogenes, and although rare, has a high mortality. The disease most often affects unborn or newly delivered infants, pregnant women, and the immunocompromised [2]. The pathogen has been consistently isolated from the production lines of fresh to cold-smoked fish [3]. A number of small outbreaks associated with smoked fish and shellfish have also been reported [4]. The survival of $L$. monocytogenes and other foodborne pathogens in apple, orange, pineapple, and white grape juice concentrates has also been studied [5].

Among the several disinfection processes available for the inactivation of food borne pathogens, the use of chlorine is banned because of the formation of organic halogens which ultimately cause environmental and ealth risks [6]. Moreover, there is a trend in eliminating chlorine from the disinfection process. Thus, there is a necessary for the usage of alternative sanitizer for conventional food 
processors. A number of commercial fruit juice processors in the US and Europe started to employ ozone for pasteurization resulting in industry guidelines being issued by the FDA [7]. Ozone is an effective sanitizer with strong disinfecting properties. Ozone rapidly decomposes into oxygen, leaving no toxic residues making it environmental friendly [8]. Ozone decomposes producing numerous free radicals, predominantly hydroxyl free radicals which increase with increasing temperature and $\mathrm{pH}$ [9]. The mechanism of ozone self decomposition has been well documented [10-12]. Since ozone has a wide antimicrobial spectrum, which together with a high oxidation potential make it an attractive option for the food industry. Use of ozone has been reported for processing of various fruit juices including; apple cider [13] and orange juice [14]. Ozone surface treatment of fruit was reported to have minor effects on anthocyanin contents in strawberries [15] and blackberries [16] . There are numerous studies in the literature about the effect of ozone treatment on the safety and quality of iceberg lettuce, orange Juice, fresh cut green lettuce[17-18], Salmon - trout [19] and blackberry juice [20]. The use of ozone as a surface disinfectant of meats [21] and for the preservation of shrimps [22], broccoli sprouts [23] and Chicken [24] has been reported. Response Surface Methodology (RSM) is a statistical tool that includes the influence of individual factors as well as their interactive effects, hence it has been successfully used to model and optimize the ozonation process. It is employed for multiple regression analysis using quantitative data obtained from properly designed experiments to solve multivariable equations. A further benefit of using the RSM is the reduction of the number of experiments needed to compare a full experimental design at the same level [25]. In this research the variables such as $\mathrm{pH}$, temperature and treatment time responsible for the inactivation of $L$. monocytogenes has been studied using ozonation process and the inactivation efficiencies were modelled using response surface methodology.

\section{MATERIALS AND METHODS}

\section{A. Bacterial culture and preparation of inoculum}

L. monocytogenes (ATCC 19115) were obtained from the Defence Food Research Laboratory in Mysore, India.
L. monocytogenes were grown aerobically at $35^{\circ} \mathrm{C}$ for 24 $\mathrm{h}$ in Trypticase soy broth (TSB) (HiMedia, Mumbai, India) and stored at $-70{ }^{\circ} \mathrm{C}$ in TSB containing $10 \%$ glycerol (HiMedia, Mumbai, India). Prior to experiment, $L$. monocytogenes were propagated aerobically in TSB at $35^{\circ} \mathrm{C}$ for 18 h. L. monocytogenes cultures were streaked on Brain Heart Infusion agar (BHI, Hi Media, Mumbai, India) and incubated at $37^{\circ} \mathrm{C}$ for $24 \mathrm{~h}$. A single colony was chosen for further use, added into $50 \mathrm{~mL}$ tubes containing $10 \mathrm{~mL}$ of selective medium, and incubated overnight shaking at $37^{\circ} \mathrm{C}$ (150 rpm). $1 \mathrm{~mL}$ of overnight culture was transferred to $100 \mathrm{~mL}$ of each fresh medium and was incubated at $37^{\circ} \mathrm{C}$ for $24 \mathrm{~h}$. After incubation, culture was centrifuged at $2000 \mathrm{xg}$ for $15 \mathrm{~min}$ at $4{ }^{\circ} \mathrm{C}$. Cell pellets were washed twice in peptone water $(0.1 \%$ sterile peptone, w/v). For each investigation, the cell concentration was further diluted in $1 \mathrm{~L}$ of sterile Phosphate buffered saline to yield a final concentration of $10^{8} \mathrm{CFU} / \mathrm{mL}$ and then ozone treatment was applied.

\section{Experimental Setup}

The experimental setup consisted of an oxygen concentrator (Sim Oplus, Italy), ozone generator (Ozonetek Ltd., India) with built-in oil-free compressor and reaction column. A controlled flow rate of $2 \mathrm{~L} / \mathrm{min}$ of oxygen was used to produce $2 \mathrm{~g} / \mathrm{h}$ of ozone. The reactor had a glass column of $720 \mathrm{~mm}$ height, outer diameter of $45 \mathrm{~mm}$, and an inner diameter of $35 \mathrm{~mm}$ and having a capacity to hold $1500 \mathrm{~mL}$ of a liquid sample. It was provided with a sample port at various points, an ozone gas inlet at the bottom with an air diffuser over the inlet port to diffuse the oxygen/ozone gas mixture through the column, and a closed top with a collection port to collect the unreacted ozone gas venting out. Teflon tube was used for connecting the ozone outlet port from the ozone generator to the ozone reaction chamber.

\section{B. Experimental Design-Central Composite Design (CCD)}

Response surface methodology (RSM) is a collection of statistical tools and techniques for exploring an approximate functional relationship between a response variable and a set of design variables [26]. (Myers and Montgomery, 1995). A three-level factorial design was established with the help of the Design Expert software 
(Central Composite Design Expert Version 8.0.3, Stat Ease, Minneapolis, USA). In the experimental design, model parameters were estimated by forming an optimal plan matrix using a second-degree quadratic polynomial equation:

$$
\begin{aligned}
& Y=B_{0}+B_{1} X_{1}+B_{2} X_{2}+B_{3} X_{3}+B_{11} X_{1}{ }^{2}+B_{22} X_{2}^{2}+B_{33} X_{3}{ }^{2} \\
& +B_{12} X_{1} X_{2}+B_{13} X_{1} X_{3}+B_{23} X_{2} X_{3} \quad \ldots(1) \\
& \text { Where } Y \text { predicts response (inactivation), Bo the }
\end{aligned}
$$
constant coefficient, $B_{1}, B_{2}$, and $B_{3}$ the linear coefficient, $B_{11}, B_{22}, B_{33}$ the quadratic coefficient, $B_{12}$, $B_{13}, B_{23}$ the cross-products coefficient, and $X_{1}, X_{2}$, and $X_{3}$ were input variables. The variables and their levels are designated as $-1.682,-1,0,+1$, and +1.682 (Table 1). According to the equation (1), it was found that a total of 20 runs are necessary to optimize the $L$. monocytogenes inactivation. Adequacy of the proposed model was then revealed using the diagnostic checking tests provided by analysis of variance (ANOVA). The quality of the fit polynomial model was expressed by the coefficient of determination, $\mathrm{R} 2$, adjusted $R^{2}$, and "adequate precision". The fitted polynomial equation was expressed as threedimensional (3D) surface plots to visualize individual and interactive effect of variables on the response within the design range.

Table 1: Level of factors and their values used for the experiment

\begin{tabular}{llllll}
\hline $\begin{array}{l}\text { Variables } \\
\text { coded } \\
\text { values }\end{array}$ & \multicolumn{4}{l}{ Actual values of the coded values } \\
\cline { 2 - 6 } & 1.682 & -1.000 & 0 & +1.000 & +1.682 \\
\hline $\mathrm{pH}\left(\mathrm{X}_{1}\right)$ & 4 & 5.3 & 7 & 8.7 & 10 \\
$\begin{array}{l}\text { Temperatu } \\
\text { re }\left(\mathrm{X}_{2}\right){ }^{\circ} \mathrm{C}\end{array}$ & 4 & 11.299 & 22 & 32.70 & 40 \\
Ozonation & & & & & \\
time $\quad\left(\mathrm{X}_{3}\right)$ & 5 & 16 & 32.5 & 49 & 60 \\
Sec & & & & & \\
\hline
\end{tabular}

\section{Experimental Procedure}

One liter of Phosphate buffered saline mixed with culture was transferred into the laboratory-scale batch reactor. The sample was then transferred to the ozonation chamber, and $66.6 \mathrm{mg} \mathrm{O}_{3} / \mathrm{min}$ was passed into the chamber. The experiment was carried out as per the order given in Table 2. After treatment, the sample was transferred into conical flask sealed tightly with a rubber cork for further microbiological analysis

\begin{tabular}{|c|c|c|c|c|}
\hline Run & $\mathrm{pH}$ & Temperature & Ozonation & Survival \\
\hline \multirow[t]{5}{*}{ Order } & $\left(X_{1}\right)$ & $\left(\mathrm{X}_{2}\right)\left({ }^{\circ} \mathrm{C}\right)$ & Time $\left(X_{3}\right)$ & Organisms \\
\hline & & & (Seconds) & (after \\
\hline & & & & ozonation) \\
\hline & & & & $(Y)$ \\
\hline & & & & $\mathrm{CFU} / \mathrm{mL}$ \\
\hline 1 & 5.30 & 11.00 & 49.00 & 0 \\
\hline 2 & 5.30 & 11.00 & 16.00 & 2 \\
\hline 3 & 8.70 & 11.00 & 49.00 & 12 \\
\hline 4 & 5.30 & 33.00 & 16.00 & 21 \\
\hline 5 & 7.00 & 22.00 & 5.00 & 4 \\
\hline 6 & 7.00 & 4.00 & 32.50 & 0 \\
\hline 7 & 8.70 & 33.00 & 16.00 & 14 \\
\hline 8 & 8.70 & 11.00 & 16.00 & 10 \\
\hline 9 & 8.70 & 33.00 & 49.00 & 5 \\
\hline 10 & 7.00 & 22.00 & 32.50 & 0 \\
\hline 11 & 7.00 & 22.00 & 32.50 & 0 \\
\hline 12 & 7.00 & 22.00 & 32.50 & 0 \\
\hline 13 & 10.00 & 22.00 & 32.50 & 32 \\
\hline 14 & 5.30 & 33.00 & 49.00 & 0 \\
\hline 15 & 7.00 & 22.00 & 32.50 & 0 \\
\hline 16 & 7.00 & 22.00 & 32.50 & 0 \\
\hline 17 & 7.00 & 22.00 & 60.25 & 0 \\
\hline 18 & 7.00 & 40.00 & 32.50 & 3 \\
\hline 19 & 4.00 & 22.00 & 32.50 & 12 \\
\hline 20 & 7.00 & 22.00 & 32.50 & 0 \\
\hline
\end{tabular}

Table 2: The design matrix and observed values of the central composite design 


\section{Microbiological analysis}

After ozonation, $1 \mathrm{~mL}$ of the sample in triplicate were evenly spread on the surface of the Listeria selective agar PALCAM (Hi Media, India) supplemented with modified Listeria selective supplement (FD061, Hi Media, India) plates aseptically. Each plate was incubated at $37^{\circ} \mathrm{C}$ for $48 \mathrm{~h}$ respectively. Each microbial count was the mean of three determinations, expressed as CFU/mL.

\section{RESULTS AND DISCUSSION}

\section{A. Statistical Analysis and Fitting of Second-Order Polynomial Equation}

Response surface methodology is an empirical modeling technique, where the relationship between a set of controllable experimental factors and observed results are evaluated [27]. Quite a number of factors persuade the inactivation of $L$. monocytogenes, of which $\mathrm{pH}$, temperature and ozonation time plays a vital role. In order to study the combined effect of these variables, experiments were performed in different combinations using statistically designed experiments. The results of response for survival of the organism after inactivation $\left(Y_{1}\right)$ are shown in Table 2. To decide the adequacy of various models to represent the inactivation efficiency, two different tests, namely the sequential model sum of squares and model summary statistics were carried out and the results are given in Table 3 and Table 4.
Table 3. Analysis of variance (ANOVA) for the fitted quadratic model

\begin{tabular}{|c|c|c|c|c|c|c|}
\hline Source & $\begin{array}{c}\text { Coefficient } \\
\text { estimate }\end{array}$ & $\begin{array}{l}\text { Sum of } \\
\text { squares }\end{array}$ & DF & $\begin{array}{l}\text { Mean } \\
\text { square }\end{array}$ & $\begin{array}{c}F \\
\text { value }\end{array}$ & $\begin{array}{c}\text { Prob } \\
>F\end{array}$ \\
\hline Model & & 1359.39 & 9 & 151.04 & 18.34 & 0.0001 \\
\hline Intercept & 96.90 & & & & & \\
\hline$X_{1}$ & -33.49 & 195.23 & 1 & 195.23 & 23.70 & 0.0007 \\
\hline$X_{2}$ & +1.72 & 32.43 & 1 & 32.43 & 3.94 & 0.0753 \\
\hline$X_{3}$ & -0.32 & 98.77 & 1 & 98.77 & 11.99 & 0.0061 \\
\hline$X_{1} \times X_{2}$ & -0.15 & 60.50 & 1 & 60.50 & 7.35 & 0.0219 \\
\hline$X_{1} \times X_{3}$ & +0.07 & 32.00 & 1 & 32.00 & 3.89 & 0.0770 \\
\hline$X_{2} \times X_{3}$ & -0.02 & 112.50 & 1 & 112.50 & 13.66 & 0.0041 \\
\hline$x_{1}{ }^{2}$ & +2.62 & 824.50 & 1 & 824.50 & $\begin{array}{c}100.1 \\
1\end{array}$ & $\begin{array}{c}<0.000 \\
1\end{array}$ \\
\hline$x_{2}{ }^{2}$ & +2.61 & 1.44 & 1 & 1.44 & 0.17 & 0.6848 \\
\hline$x_{3}^{2}$ & +1.81 & 3.50 & 1 & 3.50 & 0.42 & 0.5292 \\
\hline Residual & & 82.36 & 10 & 8.24 & & \\
\hline $\begin{array}{c}\text { Lack of } \\
\text { Fit }\end{array}$ & & 82.36 & 5 & 16.47 & & \\
\hline $\begin{array}{l}\text { Pure } \\
\text { Error }\end{array}$ & & 0.000 & 5 & 0.000 & & \\
\hline Cor Total & & 1441.75 & 19 & & & \\
\hline
\end{tabular}


Table 4. Model Summary Statistics

\begin{tabular}{|c|c|c|c|c|c|}
\hline Source & S.D & $R^{2}$ & $\begin{array}{l}\text { Adjusted } \\
R^{2}\end{array}$ & $\begin{array}{l}\text { Predicted } \\
R^{2}\end{array}$ & PRESS \\
\hline Linear & 8.35 & 0.2264 & 0.0814 & -0.3172 & 1899.05 \\
\hline $2 \mathrm{FI}$ & 8.37 & 0.3686 & 0.0772 & -0.3774 & 1985.87 \\
\hline Cubic & 0.74 & 0.9977 & 0.9928 & 0.4963 & 726.16 \\
\hline
\end{tabular}

In the model of inactivation of $L$. monocytogenes $(Y)$ the probability value of $<0.0001$ implies that this model was significant. To test the estimated regression equation for the goodness of fit, Fisher's F-test was employed and the multiple correlation coefficient $\mathrm{R}^{2}$ was calculated. The model $\mathrm{F}$-value 18.34 implies that the model is significant for inactivation of $L$. monocytogenes. The ANOVA results for the response $Y$ (survival of organisms), showed that the significant $(P<0.01)$ model with high $R^{2}$ value of 0.9429 . Quadratic model was found to be maximum in adjusted $R^{2}(0.8915)$. Hence, quadratic model was chosen for further analysis. The lack of fit (LOF) F-value of this model implies the variation of data around the fitted model and shows significance. The experimental results were evaluated and the response, survival of organisms after treatment were obtained in the form of following regression equations (Eq.2),

Survival of L. monocytogenes $(\mathrm{Y})=+96.9017$ $33.4994(\mathrm{pH})+1.7261($ Temp) -0.3252 (Time) -0.1471 $\left(\mathrm{pH}^{*}\right.$ Temp $)+0.07130\left(\mathrm{pH}^{*}\right.$ Time $)-0.0206\left(\right.$ Temp ${ }^{*}$ Time $)+$ $2.6172(\mathrm{pH})^{2}+0.0026\left(\right.$ Temp) ${ }^{2}+0.0018$ (Time) ${ }^{2} \ldots$ (2)

Data were also analyzed to check the normality of the residuals. A normal probability plot of the residuals is shown in Fig 1. in which the actual values are the measured response data for a particular run and the predicted values are evaluated from the model and generated by the approximating the functions. A normal probability plot indicates whether the residuals follow a normal distribution, in which case the point will follow a straight line. The data points on the plot lie reasonably close to a straight line and it concludes that the data is fairly distributed.
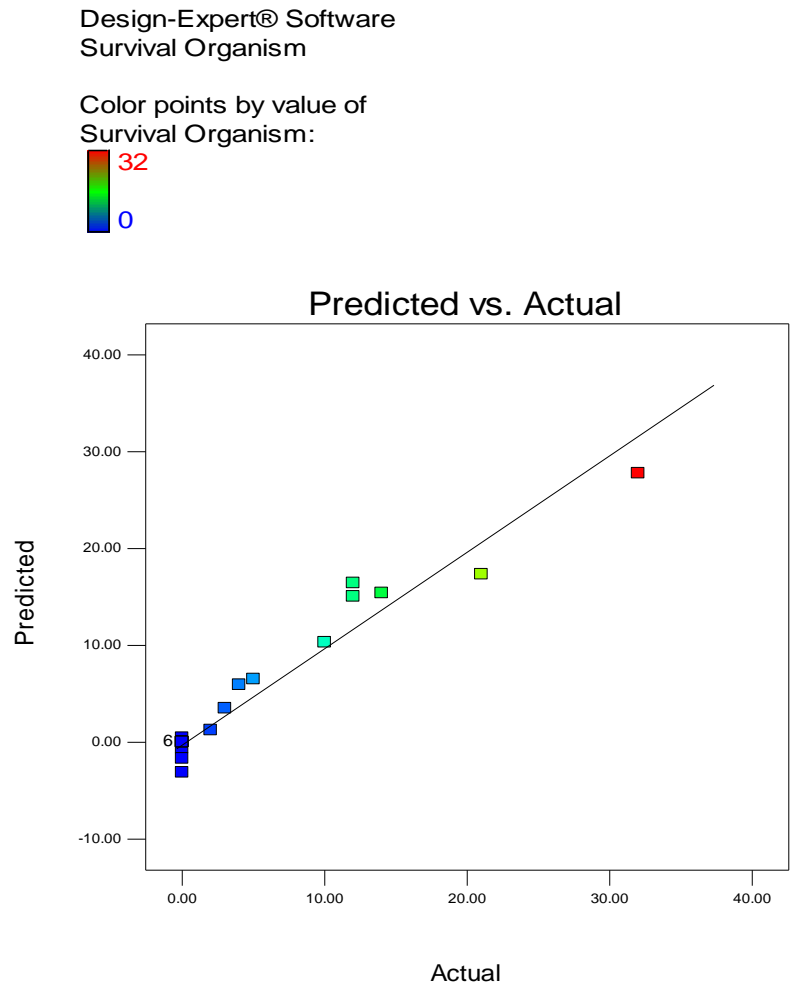

Fig 1. Normal Probability plot of actual and predicted values

\section{B. Effect of $\mathrm{pH}$}

The $\mathrm{pH}$ and type of acid play a major role in the inactivation of bacteria. Two inhibitory mechanisms involved in inactivation process are an intracellular acidification process (loss of homeostasis) and a specific effect of the acid (non-dissociated form) on metabolic activities. Inactivation efficiency of $L$. monocytogenes to specific $\mathrm{pH}\left(\mathrm{X}_{1}\right)$ was studied by varying the $\mathrm{pH}$ from 4 to 10 of the phosphate buffered saline mixed with the same. The results obtained are shown in Fig. 2 and 3. From the figure it was observed that at a given temperature and time, increasing $\mathrm{pH}$ from acidic to neutral shows increasing inactivation. After neutral towards alkaline $\mathrm{pH}$, efficiency of inactivation decreases. The $\mathrm{pH}$ between 4.5 and 7.5 shows the optimum range for the inactivation. $L$. monocytogenes maintains its intracellular $\mathrm{pH}$ within a narrow range of 7.6-8.0 and an extracellular $\mathrm{pH}$ value of 4.0 to 8.0 [28]. In this study it was observed that in similar conditions, at varying $\mathrm{pH}$ from 4 to $5, L$. monocytogenes survival was around $30 \mathrm{CFU} / \mathrm{mL}$ to 3 $\mathrm{CFU} / \mathrm{mL}$. Whereas when the $\mathrm{pH}$ was increased gradually 
from 5.5 to 7.5 there was a complete inactivation. An increase in $\mathrm{pH}$ from 8 to 10 the CFU/mL increased from 2 to 28. In this study it was found that low intracellular $\mathrm{pH}$ was not the major factor in the inhibition of $L$. monocytogenes. In fact, cells treated with organic acids or $\mathrm{HCl}$ at $\mathrm{pH}$ values as low as 3.5 were able to maintain their cytoplasmic pH near 5.0 [29].

The organism can become highly resistant to even extremely acidic conditions due to stress hardening [30]. Applying a mild acid stress actually increased the ozone treatment time required for a 5 log reduction of $L$. monocytogenes by comparison with the control population. It has been reported that $\mathrm{pH}$, heat and acid resistance of $L$. monocytogenes are strain dependant [3132].
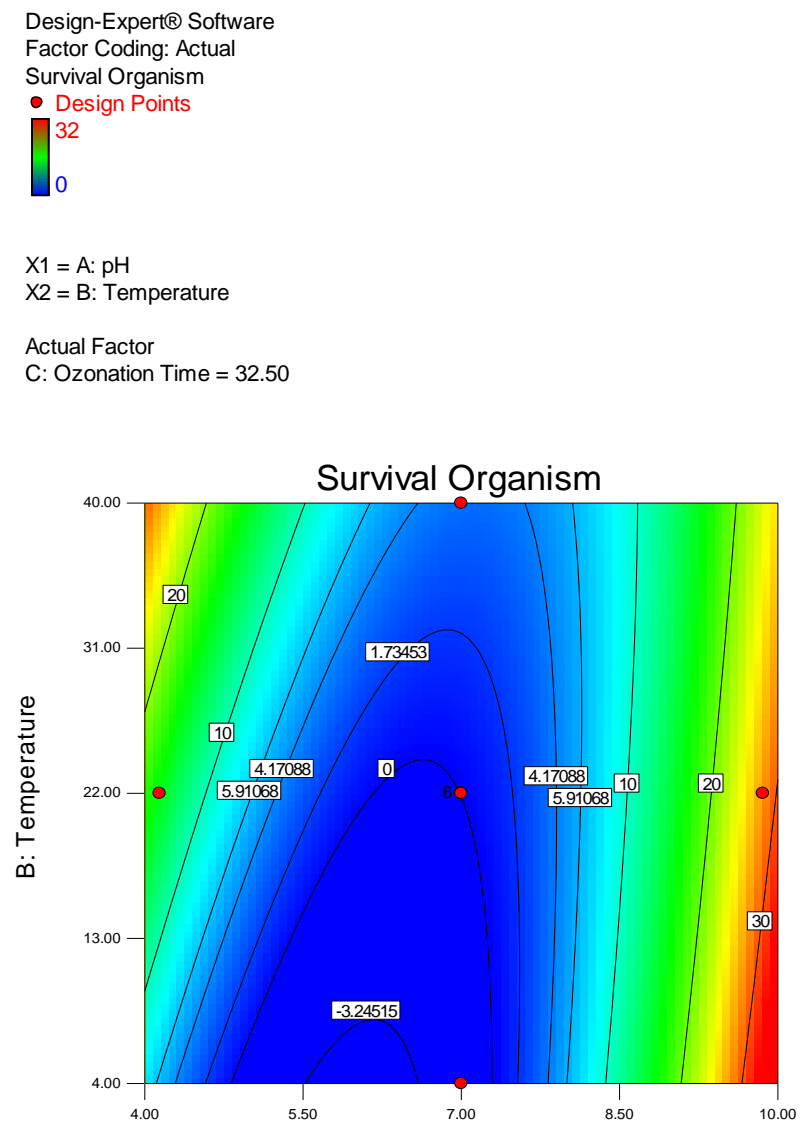

$\mathrm{A}: \mathrm{pH}$
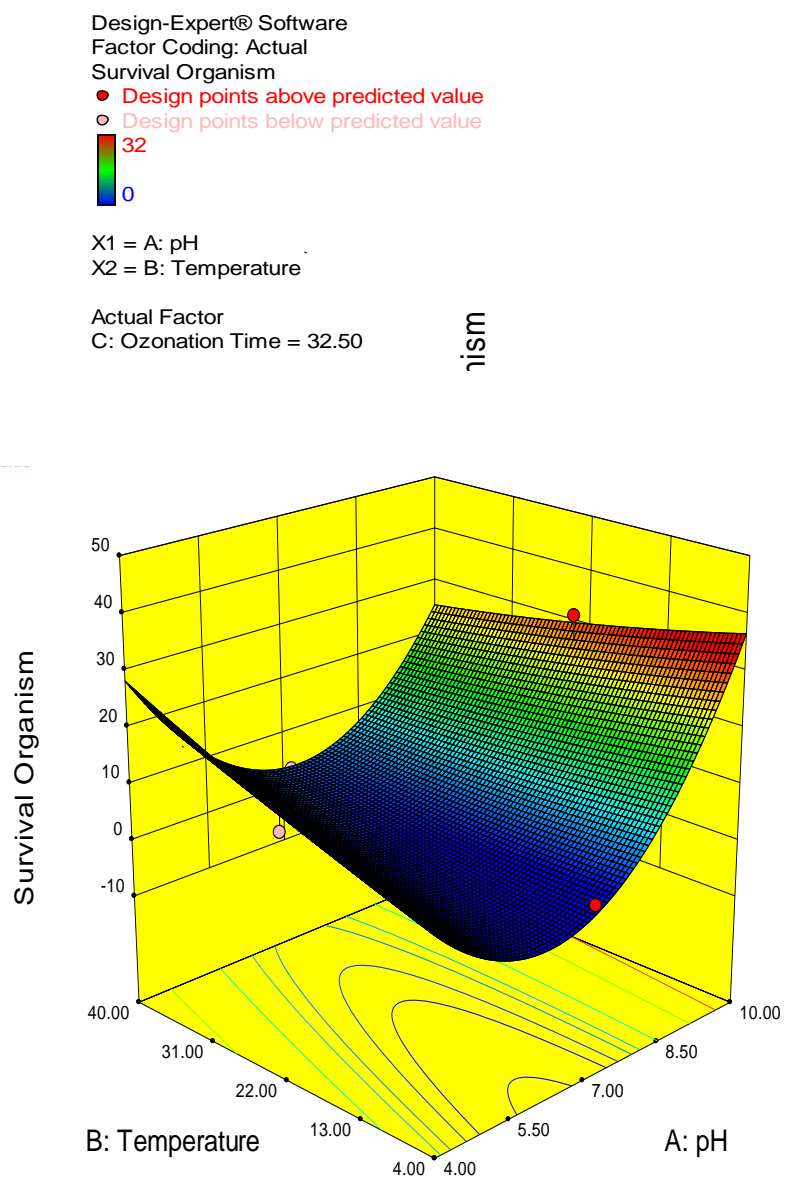

Fig. 2 Effect of pH and temperature on inactivation of Listeria monocytogenes

Fig. 3 Effect of pH and Ozonation time on the inactivation of Listeria monocytogenes
Design-Expert $\circledast$ Software Factor Coding: Actual

32

$\mathrm{X} 1=\mathrm{A}: \mathrm{pH}$

X2 = C: Ozonation Time

Actual Factor

B: Temperature $=25.00$ 


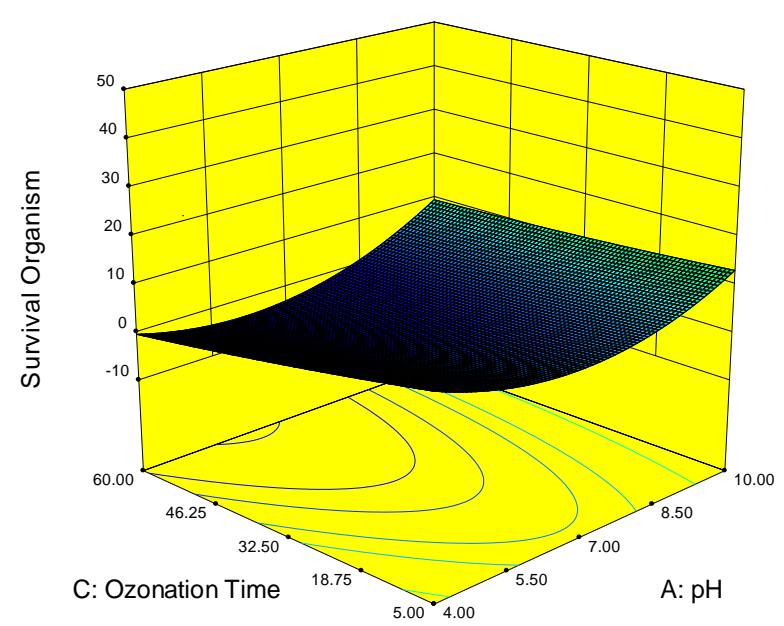

Figure 4 Effect of Temperature and Ozonation time on the survival of Listeria monocytogenes

\section{C.Effect of ozonation time}

To find the effect of ozonation time on the inactivation efficiency of $L$. monocytogenes experiments were conducted by varying the ozonation time $\left(X_{3}\right)$ from 5 to 60 seconds. The results achieved are shown in FIG 3 and 4. The results revealed that increase in time increased the efficiency of ozonation. In this study, 33 seconds to 49 second exposure to ozone successfully inactivated $10^{8}$ $\mathrm{CFU} / \mathrm{ml}$ of $L$. monocytogenes and achieved a $7 \mathrm{log}$ reduction. According to an ozonation study conducted using a batch reactor, conducted by, for the inactivation of $L$. monocytogenes. The treatment was most effective during the first 15 or 30 seconds while the counts of the organisms continued the similarity when the organism was exposed to the same dose till 6 min [39]. Whereas in a continuous reactor study conducted by the same authors most of the decrease in count occurred during the first 5 seconds of the treatment and the count of $L$. monocytogenes decreased gradually as contact time increased this kinetic pattern is more distinctive than that seen in other bacteria. Effective inactivations of $L$. monocytogenes to ozone exposure than other pathogenic microorganisms were well studied by Restaino et al., [40] who reported that even in the presence or absence of organic material, $L$. monocytogenes was more sensitive to ozonated water than the other Gram-positive and Gram-negative bacteria. This study produced unique results of inactivating the Gram-positive $L$. monocytogenes exposed less than 60 seconds where many authors have obtained the same results by exposing more than a minute [33]

\section{CONCLUSION}

In conclusion, $L$. monocytogenes at an initial population of $8 \log \mathrm{CFU} / \mathrm{mL}$ were inactivated using ozone. Three variables such as $\mathrm{pH}$, temperature and ozonation time responsible for the inactivation of $L$. monocytogenes were optimized using response surface methodology. The model obtained has been validated and is expected to give reliable predictions in the specified ranges. It should be understood that the results used for developing this model is specific to the L. monocytogenes strain used in this study that can further be extended to other strains as well.

\section{CONFLICT OF INTEREST STATEMENT}

The author declare that there is no conflict of interest

\section{ACKNOWLEDGEMENTS}

Funding for this research was provided under the Fast Track Young Scientist Fellow Scheme of Department of Science and Technology, Govt of India. The Author is thankful to DRDO -BU- CLS for the facilities provided to execute the Project.

\section{REFERENCES}

[1] Emmanuel. R., 2000, Summertime Urban Heat Island Mitigation: Propositions based on an investigation of Intra-Urban air temperature variations, Architectural Science Review, 40 (4), pp. 155-164.

[2] Fruin, J.J., 1971, Pedestrian: planning and design, Metropolitan Association of Urban Designers and Environmental Planners, Inc., New York.

[3] Chang. P.C., 2003, HACCP Update in fish process in Taiwan. In: Hwang DF,Noguchi T, (Eds.), Proceedings of international scientific symposium on marine toxins and marine food safety, Keelung: National Taiwan Ocean University, pp.137-141.

[4] Farber, J.M., Peterkin, P.I., 1991, Listeria monocytogenes, a foodborne pathogen. Microbiogical Reviews, 55, 476-511.

[5] Jørgensen, L.V., 2000, Spoilage and safety of cold-smoked salmon. Ph.D. Thesis, Royal Veterinary and Agricultural 
University of Copenhagen. Edited by Danish Institute for Fisheries Research, Technical University of Denmark.

[6] Miettinen, M.K., Siitonen, A., Heiskanen, P., 1999, Molecular epidemiology of an outbreak of febrile gastroenteritis caused by Listeria monocytogenes in cold-smoked rainbow trout. Journal of Clinical Microbiology, 37, 2358-2360.

[7] Oyarzábal, O.A., Nogueira, M.C.L., Gombas, D.E., 2003, Survival of Escherichia coli 0157:H7, Listeria monocytogenes, and Salmonella in Juice Concentrates. Journal of Food Protection , 66, 1595-1598.

[8] Dychdala, G.R., 1991, Chlorine and chlorine compounds. In: Block, S.S. (Ed.), Disinfection Sterilization and Preservation, fourth ed. Lea and Febiger, Philadelphia, 131-151

[9] FDA, 2004. FDA guidance to industry Recommendations to processors of apple juice or cider on the use of ozone for pathogen reduction purposes. http://www.cfsan.fda.gov/ 2004.

[10] Tiwari, B.K., Muthukumarappan, K., O'Donnell, C.P., 2008, Modelling colour degradation of orange juice by ozone treatment using response surface methodology, Journal of Food Engineering, 88, 553-560.

[11] Graham, D.M.., 1997, Use of ozone for food processing, Food Technology, 51, 121-137.

[12] Staehelin J ,Hoigné J. Decomposition of ozone in water: Rate of initiation by hydroxide ions and hydrogen peroxide. Environ Sci Tech 1982; 16: 676-681.

[13] Staehelin, J., Buhler, R., Hoigné, J., 1999, Ozone decomposition in water studied by pulse radiolysis, Journal of Physical Chemistry, 88, 5999-6004

[14] Tomiyasu H, Fukutomi H,Gordon G. Kinetics and mechanism of ozone decomposition in basic aqueous solution. Inorg Chem 1985; 24: 2962-2966.

[15] Steenstrup, L.D., Floros, J.D., 2004, Inactivation of E. coli 0157:H7 in apple cider by ozone at various temperatures and concentrations, Journal of Food Protection and preservation, 28, 103-116

[16] Angelino, P.D., Golden, A.M., Mount, J.R.,2003, Effect of ozone treatment on quality of orange juice. IFT Annual Meeting Book of Abstract, Abstract No. 76C-2 Chicago, IL: Institute of Food Technologists

[17] Perez, A.G., Sanz, C., Rios, J.J., 1999, Effects of ozone treatment on postharvest strawberry quality. Journal of Agricultural food Chemistry, 47, 1652-1656.

[18] Barth, M.M., Zhou, C., Mercier, M., 1995, Ozone storage effects on anthocyanin content and fungal growth in blackberries, Journal of Food Sciences, 60, 1286-1287

[19] Hassenberg, C., KIdler, E., Molloy, 2007, Use of ozone in a lettuce-washing process: an industrial trial. Journal of Science Food and Agriculture, 87,914-919.
[20] Hülya Ölmeza, Meltem Yesilçimen Akbas, 2009, Optimization of ozone treatment of fresh-cut green leaf lettuce. Journal of Food Engineering, 90, 487-494

[21] Vaz-Velho, M., Silva, M., Pessoa, J., Gibbs, P., 2006, Inactivation by ozone of Listeria innocua on salmon-trout during cold-smoke processing. Food Control, 17, 609-616.

[22] Tiwari, B.K., O'Donnell, C.P., Muthukumarappan, K., 2009, Anthocyanin and colour degradation in ozone treated blackberry juice. International Journal of Food Science and Emerging Technology, 10, 70-75.

[23] Greer ,G.G., Jones, S.D.M., 1989, Effects of ozone on beef carcasse shrinkage, muscle quality and bacterial spoilage. Canadian Institut of Food Science and Technology Journal , 22, 156-160

[24] Chen, H.C., Huang, S.H., Moody, M.W., 1992, Bactericidal and mutagenic effects of ozone on shrimp (Penaeus monodon) meat. Journal of Food Science, 57, 923-927

[25] Kim, Y.J,, Kim, M.H., Song, K.B., 2009, Efficacy of aqueous chlorine dioxide and fumaric acid for inactivating pre-existing microorganisms and Escherichia coli 0157:H7, Salmonella typhimurium, and Listeria monocytogenes on broccoli sprouts, Food Control, 20, 1002-1005.

[26] Muthukumar, A., Muthuchamy,M., 2013, Optimization of ozone in gaseous phase to inactivate Listeria monocytogenes on raw chicken samples, Food Research International ,54, 1128-1130.

[27] Myers, R.H., Montgomery, D.C., 2002, Response Surface Methodology: Process and Product Optimization Using Design Experiments, John Wiley and Sons, New York, NY, USA, 2 ${ }^{\text {nd }}$ edition

[28] Myers, R.H., Montgomery, D.C., 1995, Response Surface Methodology: Process and Product Optimization Using Design Experiments, John Wiley and Sons, New York.

[29] Box, G.E.P., Hunter, W.G, Hunter, J.S., 1978, Statistics for Experiments: An Introduction to Design, Data Analysis and Model Building. John Wiley and Sons, Inc., New York

[30] Budu-Amoako, E., Toora, S., Walton, C., 1992, Thermal death times for Listeria monocytogenes in lobster meat., Journal of Food Protection, 55, $211-213$.

[31] Ita, P.S., Hutkins, R.W., 1991, Intracellular pH and survival of Listeria monocytogenes Scott $A$ in tryptic soy broth containing acetic, lactic, citric, and hydrochloric acids, Journal of Food Protection, 54, 15-19.

[32] Lou, Y., Yousef, A.E., 1997, Adaptation to sublethal environmental stresses protect Listeria monocytogenes against lethal preservation factors. Applied and Environmental Microbiology, 63, 1252-1255

[33] Patil, S., Valdramidis, V.P., Cullen, P.J., 2010, Ozone inactivation of acid stressed Listeria monocytogenes and Listeria innocua in orange juice using a bubble column, Food Control, 21, 1723-1730 
[34] Phan-Thanh, L., Mahouin, F., Alige, S., 2000, Acid responses of Listeria monocytogenes, International Journal of Food Microbiology, 55, 121-126.

[35] Christopher, W., Fisher, Dongha Lee, Beth-Anne Dodge, 2000, Influence of catalase and superoxide dismutase on ozone inactivation of Listeria monocytogenes, Applied Environmental Microbiology, 66, 1405-1409.

[36] Ingram, M.,Haines, R.B., 1949, Inhibition of bacterial growth by pure ozone in the presence of nutrients, Journal of Hygiene, 47,146-158.

[37] Kaess, I.G., Weidemann , J.F., 1968, Effect of low concentrations of ozone on microbial spoilage and surface colour of beef. International Journal of Food Science and Technology, 3, 325-334.

[38] Rice, R.G., Farguhar, J.W., Bollyky, L.J., 1982, Review of the Applications of Ozone for Increasing Storage Times of Perishable Foods, Ozone Science and Engineering, 4 147163.

[39] Bablon, G., Bellamy, W.D., Bourbigot, M.M.,1991, Fundamental aspects. In: Langlais,G., Reckhow, D.A., Brink, D.R., (Eds.), Ozone in water treatment: Application and Engineering ,Chelsea, Mich., USA: Lewis Publishers, Inc. pp. 133-316

[40] Wynn, C.S., Kirk, B.S., McNabney, R., 1973, Pilot plant for tertiary treatment of wastewater with ozone. EPA Report R2-73146, US EPA, Municipal Environ. Res. Lab., Cincinnati, Ohio
[41] Kim, J.G. ,Yousef, A.E., 2000, Inactivation Kinetics of Foodborne Spoilage and Pathogenic Bacteria by Ozone. Journal of Food Science, 65, 521-528.

[42] Restaino, L., Frampton, E.W., Hemphill, J.B., 1995, Efficacy of ozonated water against various food-related microorganisms. Applied Environmental Microbiology, 61, 3471-3475.

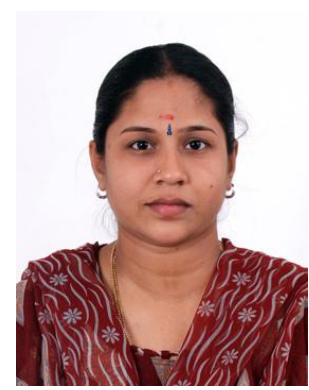

Dr. Anbazhagi Muthukumar, a postdoctoral researcher from India. Presently, she is a young scientist fellow of the Department of Science and Technology, India who is actively involved in the inactivation of foodborne pathogens. 